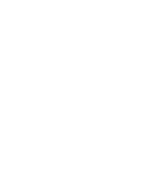

\section{REVIEWS Further}

Click here for quick links to Annual Reviews content online, including:

- Other articles in this volume

- Top cited articles

- Top downloaded articles

- Our comprehensive search

\title{
The Legal Complex
}

\section{Lucien Karpik $^{1}$ and Terence C. Halliday ${ }^{2}$}

${ }^{1}$ Centre Raymond Aron (EHESS), École de Mines, 75272 Paris, France; email: karpik@paris.ensmp.fr

²American Bar Foundation, Chicago, Illinois 60611; email: halliday@abfn.org
Annu. Rev. Law Soc. Sci. 2011. 7:217-36

First published online as a Review in Advance on September 1, 2011

The Annual Review of Law and Social Science is online at lawsocsci.annualreviews.org

This article's doi:

10.1146/annurev-lawsocsci-102510-105512

Copyright (c) 2011 by Annual Reviews. All rights reserved

$1550-3585 / 11 / 1201-0217 \$ 20.00$

\section{Keywords}

political liberalism, lawyers, rights, collective action, markets

\begin{abstract}
The concept of the legal complex is a new addition to the lexicon of sociology and sociolegal scholarship. As a concept, the legal complex emerged from a series of interdisciplinary collaborations and primary research on the politics of lawyers and judges across the world. The review introduces this new collective actor to the political stage and elaborates its defining elements, morphology, varieties of mobilization, and repertoires of action. This review argues for a complementary methodological strategy for investigation of the politics of the legal complex, the longue durée and événements. With respect to political liberalism, it shows the contexts and resources in which the legal complex thrives, with particular emphasis on civil society, information technology, the rise of constitutionalism, and international circumstances. The essay argues, however, that the explanatory reach of this concept can extend to any policymaking issues, national or supranational, that involve law, legal institutions, and legal actors. By adopting the logic of analysis developed in this review, not only do previously discrete areas of work on lawyers, judges, or prosecutors come into creative tension, but a lively politics of the legal complex will refine and extend theory across the landscape of law and society research.
\end{abstract}




\section{INTRODUCTION}

The existence of the legal complex as an empirical phenomenon was discovered and elaborated during the course of a sociohistorical enterprise devoted to the study of the relationships between lawyers and political liberalism. Our first book, Lawyers and the Rise of Western Political Liberalism (Halliday \& Karpik 1997a), was organized around a central hypothesis: in France, Germany, Great Britain, and the United States, lawyers played, and may still be playing, a central role in the birth, development, and continuity of political freedoms. These studies demonstrated a critical nexus between lawyers and civil rights. But several empirical cases showed that lawyers' relationships to judges mattered in the fight for political liberalism (Bell 1997, Ledford 1997). At the time, the studies and synthetic essays merely noted this conjunction but did not pursue it theoretically. As the scope of empirical inquiries widened to other continents and histories, however, the recurrence of lawyers' relationships with judges, and in fact their engagement with other legally trained occupations, including legal academics and civil servants practicing law, demanded conceptual clarification and designation. The naming of the legal complex as a collective actor in turn opened up further empirical questions and theoretical elaborations (Halliday et al. 2007a). This inductive and then deductive sequence of steps creates a scholarly agenda with respect not only to the dynamics and structure of the legal complex but also to wide-ranging applications across the sociolegal landscape.

This review advances the case for the salience of the legal complex as a powerful analytic tool through four steps. First, it details the interdisciplinary origins of the concept from historical inquiries into a fundamental problem in political and legal change over the longue durée. Second, it elaborates the features and theoretical potency of the concept as they are exemplified by many cross-disciplinary case studies of the rise and fall of political liberalism across history and region. Third, it demonstrates the mobility of the concept by turning to a sharply different issue- the making of global norms for international trade. Finally, the article concludes by reviewing methodological steps for scholars extending the legal complex to various problems central to interdisciplinary research in law and social science.

\section{THE LEGAL COMPLEX: A NEW COLLECTIVE ACTOR}

The origins of the legal complex as a sociological concept are to be found in a critical turn in studies of legal professions that began in the late 1980s. Prior scholarship on professions in general (Abbott 1988, Larson 1977) and legal professions in particular (Abbott 1986; Abel 1988; Abel \& Lewis 1988a,b) had focused on their control of markets. Whatever the referencesKarl Marx, Max Weber, or neoclassical economic theory-again and again lawyers' behavior was exclusively explained by the pursuit of material interests and the profession's collective action by the continuity of a monopolist strategy to extract economic rent. Papers and books repeatedly demonstrated this so-called universal law by showing the pursuit of egoistic interests behind professional morality, of material interests behind disinterestedness, of the increase in the collective control of the market behind the relationships with the state.

The critical turn began with two books on two countries, each written independently of the other. One, on the politics of the organized bar in the United States, observed that on great political issues of the 1950s and 1960sMcCarthyism, civil rights, state constitutional reforms, the independence and probity of the bench-lawyers seldom acted alone but rather through committees and alliances that included judges, legal academics, and other legal occupations. Indeed, a moral economy developed between the bar and bench, partly mutually supportive, partly oppositional (Halliday 1987). Another volume on the bar in France over the longue durée sought to show that the structural relationships between the profession of lawyers, the state, and the market since the profession was born in the twelfth century took three 
different forms (Karpik 1988, 1999). What was called the classical bar, which lasted from the eighteenth century until the middle of the twentieth, was mainly organized around political action. More precisely, the bar-through numerous and particular conflicts with the state, the church, and other political forcesbecame one of the main builders of political liberalism in France. Together, these writings demonstrated that in the United States, as in France, for long periods, lawyers were strongly oriented toward the development and maintenance of individual civil and political rights.

The demonstration that lawyers mobilized for politics in two cases raised a more fundamental question: Were the politics of lawyers in France and the United States indicative of a wider historical movement across countries in which political liberalism originated? If so, how and when did lawyers mobilize and for what elements of political liberalism? These questions launched a collective enterprise that has lasted 15 years, brought together more than 30 specialized scholars, and produced 3 collective books (Halliday \& Karpik 1997a; Halliday et al. 2007a, 2012), numerous monographs, and many articles. It can be defined by the slogan "Politics Matter" (Halliday \& Karpik 1997b; Karpik 2007, 2008). That does not mean that the market has disappeared; it is only that politics matter and that the theory should bring them together within a unitary interpretation.

The initial round of interdisciplinary collaboration brought together historians, sociologists, and political scientists to deepen empirical inquiry into the histories of four Western countries: Great Britain, France, Germany, and the United States (Halliday \& Karpik 1997a). The studies focused on a particular configuration of politics: political liberalism. It is a configuration in which lawyers play a distinctive role.

The core of political liberalism, emerging from at least the seventeenth and eighteenth centuries, clusters around three principal attributes. First, a politically liberal society has a moderate state, where power within the state is divided, whether through a separation of powers or counterbalancing courts or through a federal constitution. Second, political liberalism rests upon civil society, where associations of citizens form and govern themselves outside the control of the state, where publics can express themselves as collective actors, and in both cases associations and publics exist as centers of power to limit state power. Third, political liberalism constructs a foundation of basic legal freedoms: negative rights to protect citizens against state tyranny or arbitrary state action; core political rights that permit freedoms of speech, association, and movement; and property rights, which give citizens inalienable claims to property (for more extensive discussions of the collaborative's treatment of political liberalism, see Halliday \& Karpik 1997b, 2012; Halliday et al. 2007b; Karpik 2007, 2008).

The studies of Germany, France, Great Britain, and the United States demonstrated that indeed lawyers' politics were integral to the fortunes of political liberalism, both advances and retreats, in all countries. The conclusions of Lawyers and the Rise of Western Political Liberalism can be stated summarily:

1. In all four countries, across battles against more or less authoritarian states, conducted by a strategy that linked court trials to those in the political arena, lawyers more or less intensively fought in favor of civil and political rights;

2. Lawyers' strategies varied across countries: They were substantive or directly oriented toward the contents of the diverse rights in France; formal or based on proceduralism in Germany; with the UK and the United States in between (Halliday \& Karpik 1997c);

3. In all cases, for lawyers, political liberalism meant a limited list of specific civil rights such as equality before the law, freedom of speech, personal security, property rights, and due process of law, the so-called first generation rights or basic freedoms. Even during the nineteenth and twentieth centuries, when social and political rights developed and the claim for universal suffrage as the basis of democracy became central, lawyers kept 
rigidly to their restricted view of political liberalism;

4. Lawyers' forms of action depended on two general conditions: On the one hand, liberal action implied the autonomy of the bar and the judicial system; on the other hand, a central cleavage ran through political society - the state versus societysuch that lawyers could claim to be the spokespersons of an abstract entity called the public. Whenever such a function was socially recognized, it gave lawyers more resources to act effectively (Karpik 1997, 1999).

Although the many historical studies in Halliday \& Karpik (1997a) revealed that lawyers' politics do matter, they produced an unexpected finding: the discovery of a new collective actor. In many instances, the fact and efficacy of lawyers' politics turned on their relationships with judges and prosecutors. In France and England, courts provided a stage on which lawyers had protected space in which to bring cases and write opinions [factums, memoires judiciaires (Bell 1997, Pue 1997)] and from which to address amorphous publics (Karpik 1999). In contrast, cleavages between bench and bar inhibited the capacity of either to defend, for example, Germany's Rechtsstaat during the Weimar Republic and the onset of National Socialism (Ledford 1996, 1997). In short, configurations of lawyers' relationships with other legal occupations emerged as a crucial theoretical issue that demanded a twofold response: creation and specification of a concept that could capture the complexities of this empirical phenomenon, and systematic theoretical elaboration of its permutations for political liberalism and beyond.

The analytical and theoretical development of the legal complex proceeded through two further collaborative enterprises. One tested the generality of the political liberalism thesis and the theoretical permutations of this new collective actor, which Karpik labeled the legal complex, in studies of Latin America, East Asia, and North America during the nineteenth and twentieth centuries (Halliday et al. 2007a). Another further refined and extended the historical and comparative frames for the legal complex and political liberalism in studies of British postcolonies in South Asia, Africa, and Southeast Asia since World War II (Halliday et al. 2012). We use the 20 or so national case studies in these two volumes to exemplify the structure and dynamics of the legal complex.

\section{ELABORATING THE LEGAL COMPLEX}

The legal complex denotes a cluster of legal actors related to each other in dynamic structures and constituted and reconstituted through a variety of processes. We specify the elements of a legal complex and then review in turn and illustrate aspects of its mobilization, its varieties of structural forms, its repertoires of action, the complementary methodologies salient for its analysis, and the resources deployed by the legal complex in various settings.

\section{Morphology}

Analytically, the legal complex is defined by five general characteristics. First, it is composed by the different occupations, usually legally trained, that belong to the legal and judicial institutions of a given society and whose tasks are to create, elaborate, transmit, and apply the law (Halliday 2010b). Although legal training might be considered a sine qua non, in fact in some countries such as China individuals can act as lawyers without having either a legal qualification or a legal license, or they may have foreign or domestic legal qualifications and provide legal advice (Liu 2011). The legal complex can therefore embrace a variety of occupations: private lawyers, whether practicing in solo practice, partnerships, firms, or corporations; judges, whether in a court system or in administrative and bureaucratic settings; prosecutors, whether governmental or private [for example, private prosecutors in Latin America (Brinks 2008)]; legal academics, 
whether teaching, writing, or drafting legislation; civil servants, whether acting as drafters or appliers of regulations; legal advisors, whether as so-called barefoot lawyers or as technical specialists in global accounting firms.

Second, the concept is action oriented: Occupations can be considered part of the legal complex by their behavior in drafting, representing, advising, judging, prosecuting, teaching, and writing law. It does not refer to anyone who has a legal qualification but acts as a corporate executive or elected politician or diplomat. It refers specifically to those occupations, however labeled, that mobilize law in one or more of its many modalities.

Because it is action oriented, the concept of the legal complex becomes collective. Rather than a singular focus on "great men," "heroic leaders," or aggregated actions of many individuals, it observes collective action-of lawyers acting through bar associations, of legal academics mobilizing through networks, of advocates mobilizing publics, and of judges maintaining solidarity. This is not to exclude the vital role of leaders or heroes at particular moments on causes célèbres. Many notable examples recur in the fight for political liberalism (Bell 1994, De 2012, Widner 2001). The power of the legal complex as a concept and meta-theory lies substantially in the investigation of structures that bind collectivities for or against each other.

Third, action by the legal complex is oriented toward specific issues. For the concept to have analytic bite, it does not denote an amorphous reality of all occupations exercising all legal tasks on all issues. For the legal complex to have explanatory power, its actors and actions are specified in relation to a given issue. For the political liberalism project, that issue has been confined to the elements of political liberalism: Which occupations have mobilized for a moderate state, such as independence of the judiciary? Which have mobilized for the autonomy of the bar and civil society? Which have mobilized for basic legal freedoms, for core civil rights, for basic political rights? Following the orientation of our actors, for instance, we have consistently excluded democracy from our inquiry.

In principle, therefore, the concept of the legal complex can be applied to any issueenvironmental rights, the death penalty, trade regulation, professional monopolies, constitutional reforms-where legal occupations can mobilize, usually with the weapons of law, to influence outcomes.

Fourth, the way the concept is constructed constitutes a meta-theory. It is a structural notion. It is not defined by an aggregation of occupational segments but by the systematic relationships among legal actors (see below). It varies in its composition and interrelationships, causes and effects. It invites observers to develop the study of structural relations-the relatively stable connections among the legal actors around a specific issue.

Fifth, to emphasize the mutability of the legal complex, its action orientation is specific to a period of time or historical moment. The occupations that engage a given issue, their forms of mobilization, and their relationships and orientations to the object of their action are specified temporally (see Tables $\mathbf{1}$ and 2). The actors or actions that confronted Pakistan's military rulers in 2007-2009 were not those that confronted Pakistan's generals in the mid1970s (Aziz 2012, Ghias 2012). The lawyers and judges who ushered in Sudan's new nation on behalf of political liberalism in 1956 could no longer be found in President Nimeiri's repressive regime in the 1970s (Massoud 2012). The concept of the legal complex favors a certain historical perspective delineated by the slow transformations of relations. These structural relations can be used for comparing different countries at the same period or the same countries at different periods. As use of the concept has evolved, however, one can see that it is salient in different ways both for the longue durée and for particular événements (events).

In sum, the legal complex denotes legal occupations that mobilize on a given issue at a given historical moment, usually through collective action that is enabled through discernible structures of ties. 
Table 1 Mobilization by actors for political liberalism in specific regions and time periods (and related references)

\begin{tabular}{l|c|c|c|c|c}
\hline Lawyers & Lawyers & Judges & Academics & Civil servants & Prosecutors \\
\hline & $\begin{array}{c}\text { Singapore, 1980s } \\
\text { (Rajah 2011; 2012a,b) } \\
\text { Malaysia, 1970s-2010 } \\
\text { (Harding \& Whiting } \\
\text { 2012) }\end{array}$ & & & & \\
\hline Judges & & $\begin{array}{c}\text { Pakistan, 2005-2007 } \\
\text { (Ghias 2012, Munir } \\
\text { 2012) } \\
\text { India (Epp 2012) }\end{array}$ & & & \\
\hline $\begin{array}{l}\text { Legal } \\
\text { academics }\end{array}$ & & & $\begin{array}{c}\text { Venezuela, 2000s } \\
\text { (Perdomo 2007) }\end{array}$ & & \\
\hline Civil \\
servants & & & & $\begin{array}{c}\text { Hong Kong, 1990s } \\
\text { (Jones 2007) } \\
\text { United States, } \\
\text { 2000s (Abel 2007) }\end{array}$ & \\
\hline Prosecutors & & & & & Brazil, Argentina, \\
& & & & & $1990 \mathrm{~s}$ (Brinks \\
\hline
\end{tabular}

\section{Mobilization}

The occupational elements of the legal complex represent a set of potential actors able to mobilize on an issue. A first step is to identify which actors mobilize, whatever their orientation for or against an issue. That step in turn requires attention to the conditions of mobilization for each occupation, not least each occupation's capacity to act cohesively. Table $\mathbf{1}$ illustrates this analytic move from case studies in Asia and the Americas.
The bar. In widely divergent times and places, one or another legal occupation has acted to enhance or protect the autonomy of the bar (Karpik 2007, 2008). The Singapore Law Society sought in 1986 to comment publicly on the government's draft legislation to control the freedom of the foreign press in Singapore. Its temerity in publicly challenging the state turned an episode about the freedom of speech into a public spectacle in which the state challenged before a national television audience

Table 2 Relationships within the legal complex and orientations to political liberalism, by region and time period (and related references)

\begin{tabular}{|c|c|c|c|}
\hline Basic freedoms & Lawyers & Lawyers + judges & Lawyers + judges + others \\
\hline Support & $\begin{array}{l}\text { Japan, 1870-1930, 1960-? } \\
\text { (Feeley \& Miyazawa 2007) } \\
\text { China, 2002-2006 } \\
\text { (Halliday \& Liu 2007) }\end{array}$ & $\begin{array}{l}\text { Sudan, 1950s/1960s } \\
\text { (Massoud 2012) } \\
\text { Taiwan, 1970-1990 } \\
\text { (Ginsburg 2007) } \\
\text { Namibia, 1980s-2010 } \\
\text { (VonDoepp 2012) }\end{array}$ & $\begin{array}{l}\text { Korea, 1880-1990 (Ginsburg 2007) } \\
\text { Egypt, 1990s (Moustafa 2007b) } \\
\text { Hong Kong, 1983-2000 (Jones 2007) } \\
\text { Venezuela, 1998-2006 } \\
\text { (Perdomo 2007) } \\
\text { India (Epp 2012) }\end{array}$ \\
\hline Passive & & & Israel, 2000s (Barzilai 2007) \\
\hline Oppose/complicit & $\begin{array}{l}\text { Sudan, 1980s-2000s } \\
\text { (Massoud 2012) }\end{array}$ & $\begin{array}{l}\text { Italy, 1920-1945 (Guarnieri 2007) } \\
\text { Japan, 1920-1945 (Feeley \& } \\
\text { Miyazawa 2007) } \\
\text { Germany, 1933-1945 } \\
\text { (Ledford 1996) }\end{array}$ & $\begin{array}{l}\text { Pakistan, 1970s-1990s (Aziz 2012) } \\
\text { Chile, 1973-1990 (Couso 2007) }\end{array}$ \\
\hline
\end{tabular}


the right of the Law Society to hold the government accountable to rule-of-law standards (Rajah 2011). Whereas the Singapore Law Society was silenced, the Malaysian Bar Association since independence has conducted a running fight with the Malaysian state over the freedom of the bar association to choose its own leaders and to criticize political leaders and the courts. By adhering to an idiom of legalism, it has managed to overcome internecine leadership struggles and breakaway groups (Harding \& Whiting 2012).

Frequently, however, the bar is divided, and mobilization is partial. Jansenists represented an influential but small segment of the seventeenth-century Paris bar in its struggle against the Crown, and ultimately they were silenced by their quiescent counterparts (Bell 1994). Disunity in the bar inhibited the willingness and capacity of the Malawi and Zambian bars to act independently and critically of their authoritarian rulers in the 1990s (VonDoepp 2012). Factionalism within the Pakistani bar almost short-circuited its capacity to act with one voice in 2007 (Ghias 2012).

Courts. Courts, and constitutional courts in particular, are fundamental actors within the legal complex, but they do not invariably act on behalf of political liberalism (Feeley 2012). Only in the 2000s, argues Ghias (2012), did Pakistan's highest court begin incrementally to rein in corrupt police, object to illegal detentions, and tackle issues of free speech. Even before independence, India's Federal Court had begun to assert its independence from the colonial executive (De 2012), a foundation on which India's Supreme Court ultimately built its basic structure doctrine and asserted the autonomy of law from majoritarianism and arbitrary executive action (Epp 2012, Mate 2012).

Legal academics. Legal academics in the political liberalism literature rarely act collectively, but they did when five of Venezuela's leading law school deans stood on the steps of the Venezuelan Supreme Court to protest the erosion of basic legal freedoms (Perdomo 2007). They also did when many academics signed petitions and produced amicus briefs in protest about the Bush administration's torture of political prisoners (Abel 2007). More often, academics speak individually or fragment into opposing factions or, most often, remain silent.

Civil servants. Civil servants largely remain invisible in struggles for political liberalism. Sometimes that curtain is lifted, as Abel (2007) demonstrates for several military lawyers and judges in the United States who resisted the use of torture by the military. When Jones (2007) went behind the curtain of public administration in Hong Kong, she found that lawyers inside the state were more vigilant on behalf of some basic legal freedoms than their counterparts in the private bar. Civil servants who staff human rights commissions or ombudsmen's offices can similarly orient these state institutions to the defense of basic legal freedoms (VonDoepp 2012).

Prosecutors. Normally closely aligned with state purpose, prosecutors seldom stray from exercising the will of authoritarian rulers. Yet prosecutors eventually joined Korea's march toward political liberalism when they used their powers to prosecute corruption as a way of delegitimizing the military regime (Ginsburg 2007). And the institution of private prosecutions in Latin America led private lawyer-prosecutors in Brazil and Argentina to influence significantly the rate of arrests and convictions of police engaged in arbitrary killings of suspects (Brinks 2008).

Each of these legal occupations acted for political liberalism at particular historical junctures. In some cases, an occupation acted collectively; in others, certain leading members or rump groups acted on behalf of an occupation or sometimes instead of it. In every case, however, the fact of mobilization and the consensus around mobilization are foundational empirical questions. 


\section{Building Relationships}

The dynamism of the legal complex inheres in the structural relationships among occupations that are oriented in various ways toward certain policy outcomes. Hence it is necessary to ask: Did actors mobilize with the same orientation, e.g., in favor of some individual rights or against a repressive state? And what kinds of relationships united or divided legal occupations among themselves?

A comparative analysis in Table 2 of differing orientations to political liberalism exemplifies how structural combinations are possible from the array of actors displayed in Table 1. The policy outcome and orientation concern basic legal freedoms: Is the legal complex or some of its elements acting in support, passively, or against such defense of core civil rights? We report a simplified set of relationships in the legal complex: Are lawyers acting alone, are lawyers acting jointly with judges, or are lawyers acting with judges and others in the legal complex (Karpik 2007, 2008; Feeley 2012)?

Lawyers alone for political liberalism. Lawyers actively pursue political liberalism in three very different situations. During the Meiji period in Japan (1886-1930) and again in 1980-2000, although the administrative state remained strong, the judiciary became autonomous, as did attorneys. More and more attorneys chose to work as private lawyers rather than as career officials. Being despised, they turned against the state and developed a capacity for collective action around an antigovernment ethos. Their capacity to limit state persecution of the political opposition was small but persistent and therefore had important effects on state moderation (Feeley \& Miyazawa 2007).

In contemporary China, to defend individuals against the abuses of the state and the iron triangle of police, procuracy, and judges, only lawyers, usually opposed by bar associations, have regularly taken the risks of being fined, beaten, jailed, and even killed for the ideal of political liberalism (Halliday \& Liu 2007).
Lawyers and judges (+ others) for political liberalism. Korea, Taiwan, Egypt, and Venezuela reveal historical moments when lawyers and judges, and sometimes legal academics and legal nongovernmental organizations (NGOs), mobilized together. In Egypt, Moustafa (2007b) shows how the Constitutional Courts in the 1990s became an institutional arena in which lawyers and judges worked together with NGOs in a series of fundamental cases where the stakes were nothing less than the continuity or the reversal of the political regime. The legal complex won the first rounds but ultimately lost the fight (Moustafa 2007a). In Korea as well as in Taiwan since 1980, a Northeast Asian alliance of private lawyers, judges, and prosecutors spearheaded, in conjunction with movements in civil society, the shift from military and authoritarian regimes to politically liberal democratic regimes (Ginsburg 2007). In India, lawyers and judges, in alliance with human rights NGOs, offer the most likely alliance to make police accountable to the rule of law (Epp 2012).

Lawyers and judges passive toward political liberalism. Barzilai (2007) shows that otherwise activist and liberal coalitions of lawyers and judges, among others, sometimes become silent. In Israel, that silence is deafening, he argues, around matters to do with state security and the occupation of Palestine, all the more noticeable because the legal complex is so vocal on other matters.

Lawyers, judges, and the legal complex against basic legal freedoms. Activist attorneys and the legal complex are not always liberal in orientation. They tend to become illiberal under specific conditions. Ample evidence exists to show how the legal complex has supported regimes that violate the very basis of political liberalism, as was the case for Nazi Germany (Ledford 1997), Japan during its militaristic period (1930-1945), and at least partially for Italy (1926-1945) (Guarnieri 2007). This was also the case in Chile, which is remarkable because of Chile's long history 
as a moderate state that respected individual rights (Couso 2007). Passivity and fear likewise keep lawyers, judges, and professors away from the repressive threats of leaders in countries as diverse as Malawi and Zambia, Singapore and China. Indeed, several countries, such as Taiwan and South Korea, that later made a transition to political liberalism, suffered decades of illiberalism with a legal complex so physically repressed that it dared not oppose the regime.

When we step back from these structural configurations, it becomes clear that varieties of potential structural relationships are possible. They may be dyadic (lawyers + judges) or triadic (lawyers + judges + legal academics), or even more elaborate, for or against a given policy outcome. Opposing coalitions may also emerge in particular settings. Any number of occupational combinations are therefore possible in principle. For instance, against the system of torture established in the United States after September 11, 2001, and in response to the limited restraints of a divided judiciary, private lawyers, military lawyers, bar associations, and a few law professors raised public protests to defend fundamental civil liberties (Abel 2007), a legal complex in effect without judicial support.

Moreover, alignments by the legal complex often do not follow a simplified model in which entire occupations align for or against a given policy position. In the research on political liberalism, there are repeated cases of crosscutting cleavages where some lawyers, some judges, and some prosecutors are for an aspect of political liberalism and their counterparts are against. Most Chinese lawyers are complicit or passive toward Party control of the courts (Liu \& Halliday 2011); presumably a larger proportion of judges support ultimate political control of judicial decision-making; and even more prosecutors do so. Not infrequently, as in many Latin American countries, the bar, bench, and other legal occupations were each divided internally by party affiliations (Couso 2007). This political logic destroyed any chance of collective action based on a purely professional logic of legalism (Karpik 2007).

\section{Repertoires of Action}

If legal complexes mobilize in part or whole, what levers of power are available to them? Comparative and historical research on the legal complex provides evidence of a surprising array, and often continuities across history and region, in modes of action by the legal complex.

Inside and outside courts. As a matter of course, advocates or barristers under any name bring cases, and those cases frequently are causes célèbres, ways of getting issues onto the public agenda that may be impossible elsewhere because of censorship and limits on freedom of speech. If these are conventional lawyerly modes of utilizing the machinery of justice for lawyers' causes, it is cessation of extraordinary and ordinary court appearances that can shock rulers and arrest the attention of governments. Lawyers brought the justice system to a halt in seventeenth-century France, twentieth-century Sudan, and twenty-firstcentury Pakistan by going on strike and refusing to be complicit with governments accused of abrogating rights. If the court is a stage, then the courtroom gallery, too, offers a space for display where lawyers may gather en masse, as did 200 lawyers in Inner Mongolia to protest unjust accusations against a fellow attorney, or where respected attorneys crowded courtrooms to laugh disrespectfully at illegitimate proceedings, a technique employed by the Malaysian bar. The courthouse steps offered a dramatic backdrop to protesting Malaysian lawyers and the five Venezuelan law deans, as their images were broadcast across the media. Not least, the court allows judges a significant repertoire of possibilities to check arbitrary state power (Feeley 2012).

Lawyers in repressive settings frequently seek to influence controversial or sensitive issues not through public display but through the technicalities expressed through an idiom of legalism (Halliday 1982, Harding \& Whiting 2012). Here the purpose is less to arouse the public and more to oil the machinery of justice to political effect-but through distinctively 
legalistic methods that appear unexceptional and difficult for authorities to reject out of hand.

Lawyers in authoritarian states may give notice to authorities, and perhaps the media, that they are monitoring abuses, torture, and arbitrary killings, among others, by keeping records, identifying officials, and noting facts, all implicitly pointing to a future day of judgment. Beyond that, public petitions and records of grievances or calls for reform bring together a cross-section of the legal complex. Petitions and memoranda are sometimes carried, in a public demonstration, by legal professionals to the steps of parliament or government offices (Harding \& Whiting 2012, Munir 2012). And demonstrations can escalate into national displays of dissent by the legal complex against government actions.

Public displays are magnified by the media. Singapore's Law Society sought leverage by issuing a press release (Rajah 2011, 2012a), and the dangers that action represented to the regime were calibrated by the severity of its reactions. Pakistan's media amplified the lawyers' protests and produced iconic photos that themselves became unifying symbols of the lawyers' resistance to arbitrary state action. In contemporary China, the electronic media have become a principal conduit for China's politically liberal legal vanguard to get word out to wider publics, whether about a particular case or instance of lawyer persecution, or for broader calls for institutional change, such as Charter 08.

As spokespersons for publics. Karpik (1999) demonstrates that lawyers in seventeenth- and eighteenth-century France gained leverage well beyond their numbers by acting as spokesmen for publics. This had a double aspect. On the one hand, individual or small numbers of lawyers could claim that they spoke on behalf of all lawyers as long as other lawyers did not contest their actions. This enabled the bar to appear far stronger than it was insofar as a few lawyers could claim the authority of the whole. On the other hand, lawyers could arrogate to themselves the status of spokesmen for publics-a status claimed, if not endowed. They did so by speaking abstractly about rights that pertained to the entire notional public. Again, as long as these voices remained uncontested, the voice of the bar joined that of publics. Furthermore, lawyers could effectively constitute abstract publics, purporting to speak on their behalf and thus amplifying the volume of lawyers' claims on behalf of these fictive publics. Thus, in any setting, by these mechanisms of supposed representation, a very few lawyers, and sometimes other legal professionals, can geometrically expand their influence far beyond the meager resources they may control.

\section{Moments and Arcs of History}

To say that the legal complex may mobilize on a particular issue at a particular time does not require that every issue-moment be treated without a history or with a blind eye to institutional continuity. In their latest theoretical essay, Halliday \& Karpik (2012) present two complementary methodologies that reveal different empirical realities and permit complementary theoretical advances.

Événements. To disentangle the complex intricacies of politics within legal occupations, to map precisely the structural links or fractures among legal occupations, to discern the nuances of processes that create or solidify consensus or conflict require a methodology whose lens focuses tightly on a particular historical moment, a circumscribed issue or issues, and particular actors. By sharply demarcating the scope of an occurrence, we can then "delve deeply into issues of language power, of dramaturgy and discourse, of narratives and counternarratives, of nuance and interpretation, of scripts and actors, of doctrine and cases, of national currents and local variations" (Halliday \& Karpik 2012).

Studies of the lawyers' movement in Pakistan between 2007 and 2009 provide a kaleidoscopic illustration of how a tight focus on events reveals complexities otherwise lost in the long view. A close examination of a series of cases taken by Pakistan's highest courts shows 
that the courts themselves delegitimized the regime while legitimating themselves (Ghias 2012). This accumulation of prestige captured a public imagination that would later be set alight by the vivid TV footage of a chief justice manhandled by a police officer as Chief Justice Chaudhry was unceremoniously taken into custody. News reports across Pakistan during the lawyers' marches described a dramaturgy on the public stage with enough precision to show that this was a lawyers' campaign and not that of a conventional political party (Munir 2012). Close inspection of newspapers reveals the repertoire of the government's repressive measures and the degree of the lawyers' suffering. Not least, this intensive research uncovers the meanings that lawyers attributed to their mobilization and permits refined distinctions between economic and legalistic motivations and between neoliberal economic and liberal political ideas (Aziz 2012).

Longue durée. Although necessary, a circumscribed focus on events is not enough for theory development. Any given set of events is constrained by inertia, institutional continuities, historically settled bargains, enduring contradictions, repetitive patterns of behavior, and, underneath all these, the powerful streams of incipient shifts in economies and politics, state structures and military forces, ideas and religion. Halliday \& Karpik (2012) argue for a theory of the legal complex that embraces "the long arc of change, broad configurations of relations among institutions, and social processes visible from a longer view."

While a temporal snapshot of Pakistan's legal complex in the late 2000s may yield an image of a heroic bar marching arm-inarm with an independent judiciary, Aziz's (2012) account of Pakistan's legal complex since independence greatly complicates naive presentism. Aziz points to the contradiction within Pakistan's state at its founding between rule-of-law secular constitutionalism and the Islamic trope, to the failure of Pakistan's middle class to forge a politics undistorted by the endurance of feudal landowners, of courts that habitually legitimated each military regime as it seized power from a democratically elected government, and of lawyers who not only found themselves estranged from the courts but who were quiescent themselves in the face of arbitrary arrests and torture and the subjugation of the judiciary to political will.

Indeed, the most recent collection of essays on former British colonies (Halliday et al. 2012) offers the hypothesis that postcolonial orientations of the legal complex are influenced by colonial practices and by the ways independence itself occurred. At least three global political logics of action, decades after independence, by the legal complex around political liberalism can be discerned in the years immediately before and during the independence struggles or negotiations. Rajah (2012a,b) shows, furthermore, that the rhetoric of Singapore's authoritarian ruler was shaped by global discourses of the Cold War and, later, rule of law. The theory of the legal complex, its orientations, and its forms of mobilization, therefore, require complementary methodologies that both elongate time and compress it.

\section{Contexts and Resources}

The legal complex sits inside domestic civil societies and politics, sits astride civil society and the state, and is embedded in international contexts. The orientations and power of configurations of the legal complex in the shorter and longer term are contingent in ways not yet systematized on its contexts and resources. Some brief observations derived from the political liberalism collaborative illustrate these contingencies.

Civil society. The legal complex bears a complex relationship with civil society. Parts of the legal complex, most notably private lawyers and the organized bar, partially constitute civil society and may lead it (Halliday 2010b).

Nongovernmental organizations. Since the 1990s, lawyer-led or justice-oriented NGOs have repeatedly appeared as potential partners 
for parts of the legal complex. Some are general human rights groups (e.g., in Egypt, Venezuela, Israel) or groups that focus tightly on a particular abuse, such as police homicides (Brinks 2008). Law-related NGOs may monitor government abuses, issue manifestos, submit amicus briefs, and create ties with international NGOs (Epp 2012). In extreme situations in which the organized group either is crushed or abdicates its fight for rights, NGOs serve as an alternative platform for a few professionals to continue their struggles [for example, Sri Lanka (Udagama 2012)].

Religious groups. The alliance of fragments of the legal complex with religious groups can be observed from the earliest writings on the legal complex. A quasi-Protestant movement in the Roman Catholic church, the Jansenists, spearheaded efforts of the Paris bar to mobilize publics in the decades before the French Revolution (Bell 1994, Karpik 1999). The abbey at Montserrat provided an infrastructure for reformist judges and lawyers during Spain's dictatorship in the 1950s and 1960s (Hilbink 2007). Halliday (2010a) shows various ways that religious groups have mobilized together with the legal complex, such as providing reserve infrastructures, creating protected spaces for victims, monitoring police and regime abuses, protecting lawyers, restraining police, shaping rights consciousness, leading civil society, and placing a church's national infrastructure in service of legal complex campaigns (Halliday 2010a, pp. 63-65). An alliance with Roman Catholic and Protestant churches fortified Zambia's struggle against consolidation of a Big Man regime (Gould 2012). A disproportionate number of China's leading human rights lawyers are Protestants. Yet there are many cases in which religious groups have been complicit with authoritarian regimes: indifferent, silent, or divided. If religious groups have allied with liberal fragments of the legal complex in Brazil, Kenya, Zambia, the United States, and Singapore, they have fought against political liberalism in Argentina, Sri Lanka, and elsewhere. This opens up an extensive research agenda on the affinity of religious groups and certain religious doctrines for causes espoused by the legal complex and the social and organizational conditions under which religious groups will align with the legal complex for political liberalism and others of its causes (Halliday 2010a).

Information technology. In recent decades, the media have been able to spearhead and amplify campaigns for political liberalism, as Hilbink (2007) showed for Franco's Spain, Gould (2012) found in Zambia, Munir (2012) and Ghias (2012) detail for Pakistan between 2007 and 2009, and Moustafa (2007b) describes in Egypt during the 1990s. Yet the media can also be compromised when they are organs of the state (Liu \& Halliday 2011; Rajah 2012a,b) or driven by imperatives of the market. The proliferation of electronic media has multiplied the channels of communication between leaders of the legal complex and publics, and even repressive regimes with enormous power to create censored firewalls, such as China, find they cannot entirely control the mobilization of publics through the Internet, blogs, listservs, and Twitter-like alerts (Halliday \& Liu 2007). Running skirmishes therefore frequently occur in authoritarian regimes between rulers who seek to withhold the power of the media from the legal complex and bold lawyers and law professors who use electronic pipelines or sympathetic journalists to criticize infringements of basic legal freedoms.

The rise of constitutionalism. The rise of constitutionalism after World War II opened up a greater capacity for courts to increase their autonomy and strengthen their power vis-àvis executives and legislatures (Feeley 2012). Feeley argues that the burst of constitutionalism provided new prospects for muscular lawyer-judge alliances within the legal complex to contest state power.

International pressures. Global normative pressures on states to create constitutional courts create openings for the legal complex 
to mobilize around constitutionally authorized ideals. Research on Egypt, South Korea, and Taiwan shows how authoritarian rulers felt compelled to create constitutional courts, not least as a way to attract international capital, and these courts, once instituted, over time enabled activist lawyers, legal NGOs, and legal academics to defend basic legal freedoms.

\section{THE LEGAL COMPLEX: A MARKET APPLICATION}

In principle, the explanatory potential of the legal complex may reach any policymaking issues that involve law, legal institutions, and legal actors. To exemplify the reach of the concept and its methodological deployment, we turn from political liberalism to a sharply contrasting area of international trade law: corporate bankruptcy law. We follow the same logic as the previous section.

In the past 15 years, a global project has been under way to codify norms that will govern corporate bankruptcy regimes, especially in developing and transitional nations (Halliday \& Carruthers 2009). This project, which gathered rapid momentum with the onset of the Asian financial crisis, was led by clubs of nations (G-7, G-22), international financial institutions (International Monetary Fund, World Bank), international professional associations [International Bar Association (IBA)], powerful states (France, the United States), and global governance bodies [OECD, UN Commission on International Trade Law (UNCITRAL)]. It is an area of global normmaking that results in national lawmaking, and it involves a different kind of knowledge and different perspectives. It is a domain in which the concept and theoretical implications of the legal complex should be salient.

\section{Morphology}

Corporate bankruptcy law treats one key issue: How can law produce orderly liquidations or reorganizations of companies? Global normmaking for this area of law belongs to the sphere that affects the interests of private practitioners who advise corporations, the staff of institutions that regulate the practice of corporate bankruptcy, judges who sit in the tribunals that oversee the application of the law, accountants whose firms undertake corporate restructuring, and law professors who create and critique this body of legal doctrine. It is not likely to include criminal prosecutors, whether public or private, nor military lawyers. The members of each of these professions may have different views of global norms, depending on what is good for them and their country.

The ultimate forum for global normmaking for corporate bankruptcy was UNCITRAL (Block-Lieb \& Halliday 2007). Its Working Group on Insolvency deliberated between 1999 and 2004, at which point it produced an almost 300-page Legislative Guide for Insolvency, a set of norms with legislative recommendations intended to shape lawmaking across the world (UNCITRAL 2004). Research shows that state and nonstate delegates included all those legal occupations with potential interests in the drafting of global norms for corporate bankruptcy regimes: judges; private lawyers; law professors; legal counsel of international organizations; and civil servants with legal responsibilities for trade and commerce, justice, and international relations.

\section{Mobilization}

If the legal complex concept is inherently collective-that is, if it looks to collective action by elements or combinations of legal occupations-then the global normmaking at UNCITRAL should consist of more than professionals acting singly as entrepreneurial or public-spirited individuals.

UNCITRAL is a multilateral organization of states to which nonstate delegations have been invited to join as participating observers. If the legal complex is expressed, in one guise, as organizations of professions and, in another guise, as constitutive members of state delegations, then influence ultimately depends on a combination of the two. Nonstate delegations 
have no power per se. They have no formal votes, even if they participate seamlessly in the chamber with state delegations. Most state delegations do not have sufficient resources to mount full delegations that embrace all elements of the legal complex that administers bankruptcy regimes in practice. To this situation, we must compare the mobilization of nonstate delegations of professionals with state delegations.

Professional associations. Several of the most influential nonstate delegations at the UNCITRAL Working Group meetings comprised professional associations, for which a common organizational framework provided a springboard for representation of collective interests. The American Bar Association (ABA) and IBA sent private lawyer and professor delegates from their respective sections on business, bankruptcy, and debtor-creditor law. The International Insolvency Institute brought lawyers and judges from across the world. The International Federation of Insolvency Specialists (INSOL) sent a distinguished insolvency specialist/accountant and an expert private lawyer to represent its membership. Indeed, INSOL entered into a relationship with UNCITRAL whereby its judges' section negotiated another set of global norms, The Practice Guide on Cross-Border Insolvency Cooperation, for practitioners' and judges' applications of a previous product, The Model Law on Cross-Border Insolvency. Groupe de Réflexion sur l'Insolvabilité et sa Prévention (GRIP), a French organization of bankruptcy lawyers, insolvency practitioners, and judges, also attended UNCITRAL Insolvency Working Group sessions regularly. Delegates from each of these different professional groups participated disproportionately more often in speech-turns than the delegates from the 40 to 60 states that regularly attended. They also had disproportionately more influence on the final shape of the norms than all but a handful of state delegations.

State delegations. Collective action can be expressed through the composition of state delegations. Many delegations were represented by a single legal professional-a law professor (Germany, Spain), a judge (France, Denmark, Sweden), a civil servant (Australia, Colombia). Some others combined occupations, such as Korea (judge, professor) or Mexico (civil servant, private lawyer). The United States exemplified the most effective expression of the legal complex: Its full delegation of four members combined a government official, distinguished bankruptcy judges, and one or two leading private bankruptcy lawyers. This fully defined delegation had a powerful manifest advantage in deliberations: Whatever issue of any kind arose in negotiations, the United States always had an authoritative specialist able to express a view that implicitly carried the authority of his or her legal occupation. Although it cannot be concluded that the more a delegation integrates diverse elements of the legal complex, the more influential it is (the single judge representing France had major influence), nevertheless, it is not accidental that the single most powerful delegation-the United States-also had the most diverse and authoritative representation of the legal complex on matters of corporate bankruptcy.

Building relationships. If collective elements of the legal complex mobilized, how did they relate to each other? What processes bonded or divided (collective) actors? In UNCITRAL's Working Group, it was plausible to expect that organizations of lawyers (ABA, IBA) would enter negotiations in competition with organizations dominated by accountants (INSOL). When either side saw that it would not prevail against the other, a potentially oppositional relationship translated into a compromise based on reciprocity or a relationship of reciprocity in which each delegation was prepared to concede to the other as long as the lawyers and accountants could maintain their respective current jurisdictions over areas of work.

Close cooperation marked the relationship between the ABA and IBA, and between them and the U.S. delegation. Planning meetings before UNCITRAL sessions, constant 
consultations and allocations of responsibility during sessions, and follow-up consensus on revisions and preparations of drafts produced a sustained system of interaction, a sense of common interests, and enduring structural relationships even when issues and situations changed. That purposive effort at cohesion produced a legal complex and collective action whose impact was evident during sessions and in back rooms.

Moreover, the convergence was strong enough to create conditions for the appearance of spokespersons. Representatives of the ABA, IBA, and INSOL could speak on behalf of those organizations, drawing on their formidable national and global organizational heft, yet they did so in their own right, with limited consultation and no prospect of vetoes over delegates' judgments about appropriate positions to take on behalf of their organizations. Although it varied greatly by delegation, similar conditions applied to some state delegations, such as France, whose instructions emanated more from the delegate than the ministry.

Other nonstate delegations were effectively disengaged, neither opposing nor cooperating privately or publicly with active delegations. Whereas the U.S. delegation conferred constantly with the nonstate U.S. lawyers' groups, the UK delegation conferred not at all with the powerful professional group based in London (INSOL), and the French delegation had no continuing relationship or consultation with the French NGO GRIP. Indeed, the U.S. delegation was more likely to interact with INSOL than with the UK delegation. As a result, a potential alliance between a UK delegation of civil servants and a UK practitioner group, or a potential alliance between the French delegation led by a judge and private practitioners in GRIP, never emerged.

One or two delegations withdrew because they disagreed with the direction of the drafting, notably the pioneering Asian Development Bank. The International Law Organization attended once, to raise (unsuccessfully) an issue dear to it, and then not again. Unlike some other UNCITRAL Working Groups, no nonstate delegation maintained continuing opposition. Initially, the World Bank seemed to shun working group sessions but later determined to attend and participate. Because the European Union is not itself a member of the General Assembly, it chose not to observe as a nonstate delegation.

Thus, coalitional structures and relational trade-offs between different elements of the legal complex combined to produce an outcome directly proportional to the mobilization skill of activist delegations, both nonstate and state. The delegations that forged the strongest cooperative and continuing liaison-the U.S. legal complex-had commensurately greater influence than any other combination of delegations.

\section{The Long View and Events}

A synchronic analysis of the legal complex denies theory the conditions that shape a particular event and robs that event of explanatory depth. A brief contrast of the orientations from the longue durée and specific events shows the value to be extracted from complementary methodologies.

Longue durée. Drafting the Legislative Guide on Insolvency was the culmination of a long recursive episode that reached back to national reforms of the U.S. Bankruptcy Code (1978) and the English Insolvency Act (1986) (Carruthers \& Halliday 1998, ch. 2). The ABA and what later became INSOL respectively laid down foundations for collective action in the 1990s. The rising volume of cross-border trade and the increased number of failures of multinational corporations created pressure for all parties to find legal recourse to handle cross-border insolvencies. When UNCITRAL broached this topic in the mid-1990s, it did so jointly with INSOL, quickly joined by U.S. practitioners active in the ABA and IBA. Production of the Model Law on Cross-Border Insolvency by UNCITRAL in 1999 (UNCITRAL 1999) consolidated working relationships among prominent lawyers, judges, and law professors, together with INSOL's accountants and lawyers. Those deliberations created a set 
of working relationships that emboldened UNCITRAL to take on a much more difficult task-drafting the outlines of national bankruptcy regimes.

The post-1989 construction of market economies in the former Soviet empire, the debt crises of Mexico and Russia, and the Asian financial crisis precipitated a wave of global normmaking by the International Monetary Fund (private lawyers, corporation lawyers, law professors), the World Bank (lawyers, judges, law professors), and the Asian Development Bank (lawyer-consultants). All these efforts drew on elements of the legal complex, especially the broad-based effort of the World Bank. UNCITRAL alone, however, had the legitimacy of a global quasi-legislature, and all these efforts were integrated, at least initially, into UNCITRAL's Working Group.

As a result, the five-year effort to produce the Legislative Guide was only possible because powerful economic forces, financial crises, and limits of trade law generated circumstances in which developing organizations and coalitions of the legal complex progressively became more cohesive, more focused, and more ambitious.

Events. Tracing the long arc of the reform cycles does not reveal the intricacies of legal complex politics in the production of a particular set of norms. Intensive study of événements reveals how coalitions in the legal complex formed and functioned, how delegations of very different composition exercised influence, and how language and positioning enabled some configurations of the legal complex to prevail over others. Three examples suffice. A close analysis of delegation and delegate attendance shows that only 10 of 129 delegations maintained a consistent and regular presence by attending more than half of the working group sessions. Three of these were professional associations inclusive of multiple legal occupations. In the tight-knit group of the 28 (of 545) most active delegates were one accountant, ten private lawyers, four judges, four law professors, and seven international and national civil servants (Halliday et al. 2009).
Among the political maneuverings of the legal complex at UNCITRAL were also so-called corridor politics carried out during coffee breaks, over lunch, and at dinner and breakfast meetings. The most successful coalition-the U.S. bloc-used breaks to explain the U.S. position when agreement seemed difficult on the floor of the chamber, invited smaller and less dominant countries to make U.S. points, and lined up U.S. bloc delegates to speak to particular issues.

Not least, the politics of the legal complex were underwritten by rituals of sociability, such as the cocktail party for all delegates sponsored by the IBA and Vienna law firms or the Legendary Dinner, by invitation only, of the International Insolvency Institute. Conviviality builds amity, which facilitates comity and is conducive to consensus.

Repertoires. Unlike the drama of street demonstrations, court protests, and press releases in campaigns for political liberalism, the legal complex at UNCITRAL then and now mobilizes in dry, technical, subdued ways in the arenas of trade lawmaking. Producing complex global scripts for bankruptcy regimes requires sophisticated layering of different types of norms upon each other-some at higher levels of generality, others at statutelike levels of specificity. Persuasion occurs through preparation of technical briefs and editing of initial versions of UNCITRAL texts. A rhetoric of legitimation underwrites otherwise formal and substantive documents (Halliday et al. 2009). Technical expedients transform substantive issues into terms most accessible to the legal complex.

In sum, the legal complex forged global norms for corporate bankruptcy reforms by combining its two expressions-various mixes of lawyers, judges, law professors, and officials within state delegations and combinations of these occupations in the nonstate delegations. This is best exemplified by the analysis of attendance, which closely approximates ultimate influence on the substantive outcomes of the negotiations. The state 
delegations-Australia (lawyer/civil servant), France (judge), Japan (law professor), Thailand (lawyer civil servants), United States (civil servant, judge, private lawyers)—negotiated most actively with the World Bank (private lawyer/civil servant, judge/civil servant) and the three main professional associations: the IBA (private lawyers), International Insolvency Institute (private lawyers), and INSOL (accountant, private lawyer).

Civil society, therefore, had a light footprint, except for professional associations. The media played no role. No other groups-labor, religious, women's groups-played a role, although there were grounds on which each might have done so in principle.

\section{THE LEGAL COMPLEX EXTENDED}

Although the concept and theory of the legal complex arose from sustained study of a particular problem-political liberalism—we have shown that it has explanatory power in an entirely different context, that of international trade law. In principle, the scope of the concept should reach across the entire expanse of the sociolegal field. Wherever legal occupations act collectively, alone, or in alliance with other legal occupations, in the making, implementing, enforcing, or disseminating of law or in leading publics or allying with civil society groups, then the method and theory of the legal complex come into play.

In fact, the independence of the concept from political liberalism can be seen by the fact that the legal complex might be deployed in the theories for which political liberalism scholarship is a counterpoint: those of market control and cause lawyering. In so many legal arenasthe shape of citizenship and the future of immigration; changes in civil justice; and the future of capital punishment, intellectual property, international human rights, social movements, and regulatory governance-collective action by legal occupations is imaginable, and if its actions are imaginable, then the legal complex becomes salient. Furthermore, scholarship on the legal complex would be enriched by examining the internal politics of race and gender among the legal occupations that constitute the legal complex because these attributes influence capacities and directions for collective action.

Just as the legal complex may be directed to domestic and international politics of law, so too the legal complex may be manifested nationally and internationally. In a number of countries in Southeast Asia, Northeast Asia, and Southern Africa, among others, domestic legal complexes appeal to international counterparts and seek to form alliances with them. Obversely, the international legal complex in areas such as human rights intervenes, sometimes by invitation and sometimes on its own recognizance, in support or chastisement of local legal complexes and governments (e.g., the IBA Human Rights Institute Reports on Singapore, Malawi, Malaysia, and Sri Lanka). In a globalizing world, the contours and orientations of the international legal complex deserve close attention.

Finally, within sociolegal and legal scholarship, two examples suggest ways that a systematic reexamination of well-entrenched areas of research in terms of the legal complex would inject new energy and insight. The extensive research and writing on political jurisprudence and the politics of courts have settled into a peculiarly silo-like existence in which courts and judges are treated as if they were entirely free of the embedding legal occupations that may provide them legitimacy, bring them cases, formulate doctrines, disseminate their rulings, build their institutional capacities, and protect them from critics. Without a proximate politics of the legal complex, a political theory of courts is incomplete, even distorted (Feeley 2012, Halliday 2011).

A burgeoning scholarship treats constitutions, their origins, variations, and dynamics (Elkins et al. 2009, Ginsburg 2002, Moustafa 2007b, Scheppele 2003). Again, it is possible to treat constitutions as freestanding formal legal norms or as institutions that appear epiphenomenal to politics. But the political liberalism project shows repeatedly that constitutional 
politics invariably are embedded within a politics of the legal complex (Aziz 2012, Ginsburg 2003, Gould 2012, Harding \& Whiting 2012, Moustafa 2007b). To bring these respective lines of research and theory into engagement will enrich the theory and practice of both.

In sum, the rich political texture that has emerged from 15 years of scholarship on the legal complex and political liberalism has similar potentialities across dynamic and moribund fields of sociolegal research. By adopting the logic of analysis developed in this essay, not only do previously discrete areas of work on lawyers, judges, or prosecutors come into creative tension, but a lively politics of the legal complex will refine and extend theory across the landscape of law and society research.

\section{DISCLOSURE STATEMENT}

The authors are not aware of any affiliations, memberships, funding, or financial holdings that might be perceived as affecting the objectivity of this review.

\section{ACKNOWLEDGMENTS}

We thank especially our coeditor, Malcolm Feeley, and the many contributors to our collective project for their contributions to the development and application of the concept of the legal complex to political liberalism and other fields.

\section{LITERATURE CITED}

Abbott A. 1986. Jurisdictional conflicts: a new approach to the development of legal professions. Am. Bar Found. Res. 7. 1986(2):187-224

Abbott A. 1988. The System of Professions: An Essay on the Division of Expert Labor. Chicago: Univ. Chicago Press

Abel RL. 1988. The Legal Profession in England and Wales. Oxford: Basil Blackwell

Abel RL. 2007. Contesting legality in the United States after September 11. See Halliday et al. 2007a, pp. 361-402

Abel RL, Lewis PSC, eds. 1988a. Lawyers in Society: The Civil Law World. Berkeley: Univ. Calif. Press

Abel RL, Lewis PSC, eds. 1988b. Lawyers in Society: The Common Law World. Berkeley: Univ. Calif. Press

Aziz S. 2012. Liberal protagonists? The lawyers' movement in Pakistan. See Halliday et al. 2012

Barzilai G. 2007. The ambivalent language of lawyers in Israel: liberal politics, economic liberalism, silence, and dissent. See Halliday et al. 2007a, pp. 247-80

Bell DA. 1994. Lawyers and Citizens: The Making of a Political Elite in Old Regime France. Oxford: Oxford Univ. Press

Bell DA. 1997. Barristers, politics, and the failure of civil society in Old Regime France. See Halliday \& Karpik 1997a, pp. 65-100

Block-Lieb S, Halliday TC. 2007. Incrementalisms in global lawmaking. Brooklyn f. Int. Law XXXII:851-903

Brinks DM. 2008. The fudicial Response to Police Killings in Latin America. New York: Cambridge Univ. Press

Carruthers BG, Halliday TC. 1998. Rescuing Business: The Making of Corporate Bankruptcy Law in England and the United States. Oxford: Oxford Univ. Press

Couso JA. 2007. When the "political complex" takes the lead: the configuration of a moderate state in Chile. See Halliday et al. 2007a, pp. 315-44

De R. 2012. Emasculating the executive: the federal court and civil liberties in late colonial India, 1942-44. See Halliday et al. 2012

Elkins Z, Ginsburg T, Melton J. 2009. The Endurance of National Constitutions. Cambridge, UK: Cambridge Univ. Press 
Epp CR. 2012. The legal complex in the struggle to control police brutality in India. See Halliday et al. 2012

Feeley MM. 2012. Judges and company: courts, constitutionalism and the legal complex. See Halliday et al. 2012

Feeley MM, Miyazawa S. 2007. The state, civil society, and the legal complex in modern Japan: continuity and change. See Halliday et al. 2007a, pp. 151-92

Ghias SA. 2012. Miscarriage of Chief Justice: lawyers, media, and the struggle for judicial independence in Pakistan. See Halliday et al. 2012

Ginsburg T. 2002. Economic analysis and the design of constitutional courts. Theor. Inq. Law 3:49-86

Ginsburg T. 2003. Fudicial Review in New Democracies: Constitutional Courts in Asian Cases. New York: Cambridge Univ. Press

Ginsburg T. 2007. Law and the liberal transformation of the Northeast Asian legal complex in Korea and Taiwan. See Halliday et al. 2007a, pp. 43-64

Gould J. 2012. Postcolonial liberalism and the legal complex in Zambia: elegy or triumph? See Halliday et al. 2012

Guarnieri C. 2007. Lawyers and statist liberalisms in Italy. See Halliday et al. 2007a, pp. 439-62

Halliday TC. 1982. The idiom of legalism in bar politics: lawyers, McCarthyism, and the civil rights era. Am. Bar Found. Res. 7. 7:911-89

Halliday TC. 1987. Beyond Monopoly: Lawyers, State Crises, and Professional Empowerment. Chicago: Univ. Chicago Press

Halliday TC. 2010a. "The conscience of society?" The legal complex, religion, and the fates of political liberalism. In The Paradox of Professionalism: Lawyers and the Possibility of fustice, ed. S Cummings, pp. 50-67. New York: Cambridge Univ. Press

Halliday TC. 2010b. The fight for basic legal freedoms: mobilization by the legal complex. In Global Perspectives on the Rule of Law, ed.JJ Heckman, RL Nelson, L Cabatingan, pp. 210-40. London/New York: Routledge

Halliday TC. 2011. Why the legal complex is integral to theories of judicial power. In How Courts Evolve: Fudicial Roles in Comparative Perspective, ed. G Silverstein, RA Kagan, D Kapiszewski. Cambridge, UK: Cambridge Univ. Press. In press

Halliday TC, Block-Lieb S, Carruthers BG. 2009. Rhetorical legitimation: global scripts as strategic devices of international organizations. Eur. Soc. Econ. Rev. 8:1-36

Halliday TC, Carruthers BG. 2009. Bankrupt: Global Lawmaking and Systemic Financial Crisis. Palo Alto, CA: Stanford Univ. Press

Halliday TC, Karpik L, eds. 1997a. Lawyers and the Rise of Western Political Liberalism: Europe and North America from the Eighteenth to Twentieth Centuries. Oxford: Clarendon

Halliday TC, Karpik L. 1997b. Politics matter: a comparative theory of lawyers in the making of political liberalism. See Halliday \& Karpik 1997a, pp. 15-64

Halliday TC, Karpik L. 1997c. Postscript: lawyers, political liberalism, and globalization. See Halliday \& Karpik 1997a, pp. 349-70

Halliday TC, Karpik L. 2012. Political liberalism in the British post-colony: a theme with three variations. See Halliday et al. 2012

Halliday TC, Karpik L, Feeley MM, eds. 2007a. Fighting for Political Freedom: Comparative Studies of the Legal Complex for Political Change. Oxford: Hart

Halliday TC, Karpik L, Feeley MM. 2007b. The legal complex and struggles for political liberalism. See Halliday et al. 2007a, pp. 1-42

Halliday TC, Karpik L, Feeley MM, eds. 2012. Fates of Political Liberalism in the British Post-Colony: The Politics of the Legal Complex. New York: Cambridge Univ. Press. In press

Halliday TC, Liu S. 2007. Birth of a liberal moment? Looking through a one-way mirror at lawyers' defense of criminal defendants in China. See Halliday et al. 2007a, pp. 65-108

Harding A, Whiting A. 2012. 'Custodian of civil liberties and justice in Malaysia': the Malaysian bar and the moderate state. See Halliday et al. 2012

Hilbink L. 2007. Politicising law to liberalise politics: anti-Francoist judges and prosecutors in Spain's democratic transition. See Halliday et al. 2007a, pp. 403-38

Jones C. 2007. 'Dissolving the people': capitalism, law and democracy in Hong Kong. See Halliday et al. 2007a, pp. 109-50 
Karpik L. 1988. Lawyers and politics in France, 1814-1950: the state, the market and the public. Law Soc. Inq. 13:707-36

Karpik L. 1997. Builders of liberal society: French lawyers and politics. See Halliday \& Karpik 1997a, pp. 101-23

Karpik L. 1999. French Lawyers: A Study in Collective Action, 1274 to 1994. Oxford: Oxford Univ. Press. Transl. 1995. Les Avocats entre le marché et l'Etat. Paris: Gallimard

Karpik L. 2007. Postscript: political lawyering. See Halliday et al. 2007a, pp. 463-94

Karpik L. 2008. Les professions libérales sont-elles solubles dans le marché? In Action publique et légitimités professionnelles, ed. T Le Bianic, A Vion, pp. 279-88. Paris: LGDJ

Larson MS. 1977. The Rise of Professionalism. Berkeley: Univ. Calif. Press

Ledford KF. 1996. From General Estate to Special Interest: German Lawyers 1878-1933. Cambridge, UK: Cambridge Univ. Press

Ledford KF. 1997. Lawyers and the limits of liberalism: the German bar in the Weimar Republic. See Halliday \& Karpik 1997a, pp. 229-64

Liu S. 2011. Lawyers, state officials, and significant others: symbiotic exchange in the Chinese legal services market. China Q. 206:276-93

Liu S, Halliday TC. 2011. Political liberalism and political embeddedness: understanding politics in the work of Chinese criminal defense lawyers. Law Soc. Rev. In press

Massoud M. 2012. Lawyers and the disintegration of the legal complex in Sudan. See Halliday et al. 2012

Mate M. 2012. 'Priests in the Temple of Justice': the Indian legal complex and the basic structure doctrine. See Halliday et al. 2012

Moustafa T. 2007a. Mobilising the law in an authoritarian state: the legal complex in contemporary Egypt. See Halliday et al. 2007a, pp. 193-218

Moustafa T. 2007b. The Struggle for Constitutional Power: Law, Politics, and Economic Development in Egypt. New York: Cambridge Univ. Press

Munir D. 2012. From judicial autonomy to regime transformation: the role of the lawyers' movement in Pakistan. See Halliday et al. 2012

Perdomo RP. 2007. Lawyers and political liberalism in Venezuela. See Halliday et al. 2007a, pp. 345-60

Pue WW. 1997. Lawyers and political liberalism in eighteenth- and nineteenth-century England. See Halliday \& Karpik 1997a, pp. 167-206

Rajah J. 2011. Punishing bodies, securing the nation: how rule of law can legitimate the urbane authoritarian state. Law Soc. Inq. In press

Rajah J. 2012a. Autboritarian Rule of Law: Legislating Illiberalism in Singapore. New York: Cambridge Univ. Press. In press

Rajah J. 2012b. Lawyers, politics and publics: state management of lawyers and legitimacy in Singapore. See Halliday et al. 2012

Scheppele KL. 2003. Constitutional negotiations: political contexts of judicial activism in post-Soviet Europe. Int. Sociol. 18:219-38

Udagama D. 2012. The Sri Lankan legal complex and the liberal project: only thus far and no more. See Halliday et al. 2012

United Nations Comm. Int. Trade Law (UNCITRAL). 1999. UNCITRAL Model Law on Cross-Border Insolvency with Guide to Enactment. New York: United Nations

United Nations Comm. Int. Trade Law (UNCITRAL). 2004. UNCITRAL Legislative Guide on Insolvency. New York: United Nations

VonDoepp P. 2012. Legal complexes and the fight for political liberalism in New African democracies: comparative insights from Malawi, Zambia and Namibia. See Halliday et al. 2012

Widner JA. 2001. Building the Rule of Law. New York: Norton 
Annual Review of

Law and Social

\section{Contents}

Science

Volume 7, 2011

The Legislative Dismantling of a Colonial and an Apartheid State

Sally Falk Moore ............................................................. 1

Credible Causal Inference for Empirical Legal Studies

Daniel E. Ho and Donald B. Rubin ..............................................17

Race and Inequality in the War on Drugs

Doris Marie Provine ................................................................... 41

Assessing Drug Prohibition and Its Alternatives: A Guide for Agnostics

Robert 7. MacCoun and Peter Reuter

The Triumph and Tragedy of Tobacco Control:

A Tale of Nine Nations

Eric A. Feldman and Ronald Bayer

Privatization and Accountability

Laura A. Dickinson

The Conundrum of Financial Regulation: Origins, Controversies, and Prospects

Laureen Snider

Corporate and Personal Bankruptcy Law

Michelle 7. White

Durkheim and Law: Divided Readings over Division of Labor

Carol 7. Greenhouse

Law and American Political Development

Pamela Brandwein

The Legal Complex

Lucien Karpik and Terence C. Halliday

U.S. War and Emergency Powers: The Virtues

of Constitutional Ambiguity

Gordon Silverstein

The Political Science of Federalism

fenna Bednar 
The Rights of Noncitizens in the United States

Susan Bibler Coutin

Innovations in Policing: Meanings, Structures, and Processes

James 7. Willis and Stephen D. Mastrofski

Elaborating the Individual Difference Component

in Deterrence Theory

Alex R. Piquero, Raymond Paternoster, Greg Pogarsky, and Thomas Loughran

Why Pirates Are Back

Shannon Lee Dawdy

The Evolving International Judiciary

Karen 7. Alter

The Social Construction of Law: The European Court of Justice and Its Legal Revolution Revisited Antonin Coben and Antoine Vauchez

\section{Indexes}

Cumulative Index of Contributing Authors, Volumes 1-7 ...................... 433

Cumulative Index of Chapter Titles, Volumes 1-7

\section{Errata}

An online log of corrections to Annual Review of Law and Social Science articles may be found at http://lawsocsci.annualreviews.org 